\title{
Uterine and embryonic metabolism after diapause in the tammar wallaby, Macropus eugenii
}

\author{
G. Shaw* and M. B. Renfree $\dagger$ \\ School of Environmental and Life Sciences, Murdoch University, Murdoch, Western Australia 6150, \\ Australia
}

\begin{abstract}
Summary. Pouch young were removed from lactating tammars to terminate embryonic diapause. Uterine metabolism was assessed at periods afterwards by incubating endometrial explants with $\left[{ }^{3} \mathrm{H}\right]$ leucine, and measuring the incorporation into acid-soluble material. Blastocysts were incubated with $\left[{ }^{3} \mathrm{H}\right]$ uridine to assess uptake and incorporation into acid-soluble material. Uterine reactivation, shown by an increase in the rate of leucine incorporation into secreted protein, was evident by Day 4 after removal of pouch young and was significantly more in both secreted and tissue protein by Day 6 . Both continued to increase in gravid and non-gravid uteri up to Day 12. By the end of pregnancy (Day 26) uterine metabolism in the gravid uterus produced 2-3 times more secreted protein than in the non-gravid uterus, demonstrating a local feto-placental influence on the uterus. Tissue incorporation had declined in endometrium of gravid and non-gravid uteri by Day 26 . Day 5 embryos were metabolically more active than in quiescence, although expansion of the embryos was not seen until Day 9.

The early reactivation of the uterus and embryo from diapause suggests that it is not triggered by the previously described peaks of progesterone and oestradiol in plasma at Day 5, although there may be an earlier, increased sensitivity to these steroids which allows uterine reactivation to precede changes in peripheral plasma concentration.
\end{abstract}

\section{Introduction}

Female tammars, like most macropodid marsupials, usually carry a diapausing embryo through lactation (Tyndale-Biscoe, Hearn \& Renfree, 1974). This diapause normally continues for 11 months, during which time the embryo shows no expansion in size or increase in cell number. If the suckled pouch young is removed or lost prematurely during the breeding season (January-May), the embryo resumes development and is born about 27 days later (Merchant, 1979).

During diapause the corpus luteum remains small and concentrations of progesterone in the corpus luteum and in peripheral plasma are low $(11.3 \mathrm{ng} / \mathrm{mg} ; 100-200 \mathrm{pg} / \mathrm{ml}$; Renfree, Green \& Young, 1979; Hinds \& Tyndale-Biscoe, 1982). After removal of pouch young the corpus luteum begins to grow, mostly by hypertrophy (Tyndale-Biscoe \& Hinds, 1981). At Day 5 after removal of young there is a surge of progesterone secretion by the corpus luteum (Hinds, Evans \& Tyndale-Biscoe, 1983) and peripheral plasma progesterone concentrations rise to a transient peak of about $450 \mathrm{pg} / \mathrm{ml}$ between Days 5 and 8 (Hinds \& Tyndale-Biscoe, 1982). Similarly, plasma oestradiol- $17 \beta$ concentrations rise from $8.3 \pm 1.2 \mathrm{pg} / \mathrm{ml}$ on Days 3 and 4 to a peak of $15.8 \pm 2 \cdot 9 \mathrm{pg} / \mathrm{ml}$ on Day 5 , coincident with the progesterone peak, and fall to $10 \cdot 5 \pm 2 \cdot 7 \mathrm{pg} / \mathrm{ml}$ on

\footnotetext{
*Present address: Department of Physiology \& Pharmacology, University of Queensland, St Lucia, Queensland 4067, Australia. $†$ Present address: Department of Anatomy, Monash University, Clayton, Victoria 3168, Australia.
} 
Day 7 (Shaw \& Renfree, 1984). From Day 10 progesterone concentrations rise again to a plateau of about $500-800 \mathrm{pg} / \mathrm{ml}$ then fall precipitously around the time of parturition (Tyndale-Biscoe, Hinds, Horn \& Jenkin, 1983; Shaw \& Renfree, 1984). This second rise of progesterone concentration is apparently not needed to maintain pregnancy, since embryos developed to term after ovariectomy at Day 8, although parturition was prevented (Tyndale-Biscoe, 1970).

During diapause, and up to Day 18 after removal of pouch young, the embryo lies free and unattached in the uterus (Renfree, 1973) and so factors triggering reactivation and maintaining growth must reach the embryo via the uterine secretions. Renfree (1973) found no difference in the protein content of uterine flushings from females during quiescence and at Day 6 after removal of young, but by Day 8 protein content had increased, and by Day 12 was almost double the concentration on Days 0-6. Likewise, the concentration of protein in uterine exudates is higher by Day 6 and markedly increases between Days 8 and 12 (Renfree, 1973; Tyndale-Biscoe, 1979; Thornber, Renfree \& Wallace, 1981).

Hinds \& Tyndale-Biscoe (1982) proposed that the early peak of progesterone may be responsible for re-initiating embryonic development after diapause, because treatment of quiescent tammars with $10 \mathrm{mg}$ progesterone/day for 10 days induces uterine secretory activity and reactivation of the embryos, leading to full term pregnancies at Days 22 and 23 after the start of injections (Renfree \& Tyndale-Biscoe, 1973). The first measurable gross morphological change in the embryo, the start of expansion, occurs about Day 8 after pouch young removal, or after about 3-4 days' treatment with progesterone, further supporting this hypothesis (Renfree \& Tyndale-Biscoe, 1973).

Metabolic reactivation occurs earlier than the first expansion. Moore (1978) incubated tammar blastocysts in the presence of $\left[{ }^{3} \mathrm{H}\right]$ uridine-monophosphate and estimated that RNA-polymerase activity was significantly higher in Day 5 blastocysts than at Day 4 and earlier stages. Thornber et al. (1981) incubated blastocysts from tammars at Days 0,5 and 10 after removal of pouch young in medium containing $\left[{ }^{3} \mathrm{H}\right]$ uridine, and found that two of the five Day 5 blastocysts incorporated uridine at about 5 times the rate seen in the Day 0 (quiescent) blastocysts, and by Day 10 the rate was substantially higher again. These data suggest that embryonic metabolic reactivation is occurring about 3 days earlier than can be observed by gross morphology.

This paper compares the time of uterine and embryonic reactivation after removal of pouch young. The rate of uptake and incorporation of $\left[{ }^{3} \mathrm{H}\right]$ uridine by blastocysts was used as an index of their reactivation, using the method of Thornber et al. (1981). Incorporation of $\left[{ }^{3} \mathrm{H}\right]$ leucine by endometrial explants in vitro provided a more sensitive measure of uterine reactivation than total protein in flushings or exudates. In addition, the leucine incorporation of some late pregnancy uteri was measured to establish whether the morphological and histological differences between the gravid and adjacent non-gravid uterus of late pregnancy females (Renfree, 1972; Renfree \& Tyndale-Biscoe, 1973) were also reflected by changes in endometrial protein metabolism.

\section{Materials and Methods}

Embryo metabolism. Groups of 4 tammars were killed by cervical dislocation on Days 0, 5, 7 and 9 after removal of pouch young in March and April (i.e. during the breeding season). Blastocysts were flushed from the uteri, washed in two changes of medium TC199 (with Earle's salts) (Flow Laboratories Australia Pty Ltd, Stanmore, N.S.W., Australia) and transferred to individual $50 \mu \mathrm{l}$ drops of incubation medium under $5 \mathrm{ml}$ sterile paraffin oil in a $10 \mathrm{~cm}$ tissue culture dish (Biggers, Whitten \& Whittingham, 1971). The incubation medium was TC199 containing $2 \cdot 2 \mathrm{MBq}$ $\left[5-{ }^{3} \mathrm{H}\right]$ uridine $/ \mathrm{ml}$ (sp. act. $932 \mathrm{GBq} / \mathrm{mmol}$ ). After incubation for $6 \mathrm{~h}$ at $37^{\circ} \mathrm{C}$ each blastocyst was quickly washed twice in $2 \mathrm{ml}$ unlabelled medium and deposited between two small pieces of glassfibre filter paper. These were placed in $1 \mathrm{ml}$ ice-cold $5 \%$ TCA for $20 \mathrm{~min}$, then washed twice in $1 \mathrm{ml}$ cold $95 \%$ ethanol for $10 \mathrm{~min}, 1 \mathrm{ml}$ ether for $5 \mathrm{~min}$ and air dried (Thornber et al., 1981). Radioactivity in the TCA supernatant and the dried filter paper was counted in $5 \mathrm{ml}$ scintillation fluid. 
Radioactivity in the filters gave an estimate of $\left[{ }^{3} \mathrm{H}\right]$ uridine incorporation into TCA-insoluble material which includes the RNA. The radioactivity in the TCA supernatant estimates uridine taken up by the blastocyst but not incorporated into RNA. Background radioactivity was determined in an equal volume of wash solution.

Endometrial metabolism. Tammars were killed at Days $0(\mathrm{~N}=3), 4(\mathrm{~N}=3), 6(\mathrm{~N}=3), 8$ $(\mathrm{N}=3), 12(\mathrm{~N}=2)$ and $26(\mathrm{~N}=2)$ after removal of pouch young and after progesterone $(\mathrm{N}=2)$ or oestradiol $(\mathrm{N}=2)$ treatment. The steroid-treated animals were bilaterally ovariectomized during seasonal quiescence. After a 5-7-day recovery period they were treated with $1 \mathrm{mg}$ progesterone or $2 \mu \mathrm{g}$ oestradiol (in oil, i.m.) daily for 2 or 3 days. These doses will give plasma concentrations of these two steroids in the physiological range (Renfree, Wallace \& Young, 1982; Ward \& Renfree, 1984, Shaw \& Renfree, 1984).

The uteri were dissected out immediately post mortem and chilled on ice, and each uterus was flushed or opened to recover any embryos (Renfree, 1973). The endometrium was gently cut free from the myometrium using fine scissors and cut into $\sim 1 \mathrm{~mm}$ cubes in a Petri dish of medium. Each replicate incubation contained about 15 of these explants and 3-5 replicates were cultured from each uterus. The explants were incubated in $0.5 \mathrm{ml}$ medium in 24-well culture dishes for $8 \mathrm{~h}$ at $37^{\circ} \mathrm{C}$ under $95 \% \mathrm{O}_{2} 5 \% \mathrm{CO}_{2}$, and were supported at the surface of the medium by a piece of glassfibre filter paper on a stainless-steel supporting grid to facilitate gas exchange. Under these conditions incorporation increased linearly with time for at least $8 \mathrm{~h}$ (Fig. 1). The medium used to flush uteri and wash tissue was TC199 supplemented with insulin (10 $\mu \mathrm{g}$ bovine insulin/ml; Commonwealth Serum Laboratories, Parkville, Melbourne, Australia). Tissue was incubated in this medium supplemented additionally with $\left[4,5-{ }^{3} \mathrm{H}\right]$ leucine (Amersham Australia Pty Ltd, Sydney, N.S.W.; sp. act. $6.9 \mathrm{TBq} / \mathrm{mmol}$ ) at a concentration of $37 \mathrm{kBq} / \mathrm{ml}$.

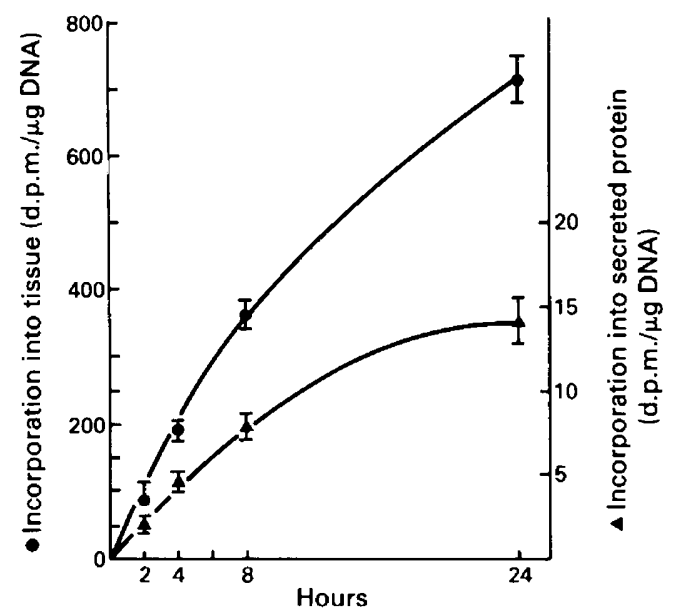

Fig. 1. Effect of incubation time on $\left[{ }^{3} \mathrm{H}\right]$ leucine incorporation by endometrium. Endometrial tissue from a Day-12 gravid uterus was incubated as described for $2,4,8$ or $24 \mathrm{~h}$. Incorporation into tissue and secreted protein increased linearly to $8 \mathrm{~h}$, but the rate of incorporation has decreased by $24 \mathrm{~h}$. Similar results were obtained using tissue from a Day-10 female (not shown).

At the end of incubation the medium was transferred to $12 \times 75 \mathrm{~mm}$ glass tubes containing $2 \mathrm{ml}$ ice-cold $10 \%$ perchloric acid (PCA). The precipitated proteins were washed 3 times in $3 \mathrm{ml}$ PCA then dissolved overnight at $30^{\circ} \mathrm{C}$ in $1 \mathrm{ml} 1 \mathrm{M}-\mathrm{NaOH}$. The filter paper with adhering tissue was placed in a separate tube with $3 \mathrm{ml}$ cold PCA then given 6 washes in $5 \mathrm{ml}$ cold PCA. This was sufficient to remove all acid-soluble radioactivity (Fig. 2) without causing a significant decrease in the assayed DNA content of the tissue. DNA in the washed tissue was hydrolysed by incubating with 
(a)

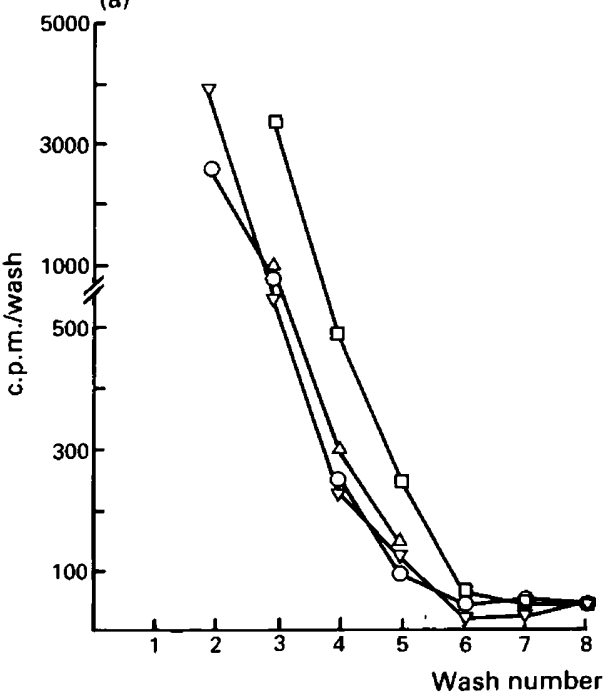

(b)

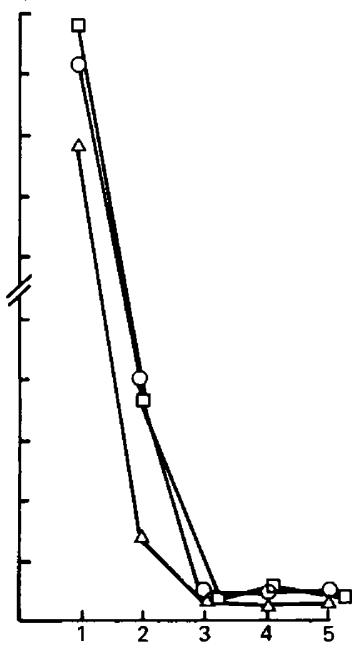

Fig. 2. Efficiency of the tissue washing used. After incubation the tissue (a) or secreted proteins (b) were washed as described, and the radioactivity in the supernatant was counted. Different symbols represent replicates from different incubation wells.

$4 \mathrm{ml} \mathrm{10 \%} \mathrm{PCA} \mathrm{at} 90^{\circ} \mathrm{C}$ for $20 \mathrm{~min}$ in a shaking water bath (Hutchison \& Munro, 1961). After cooling and centrifugation, the supernatant was assayed for DNA by the diphenylamine method of Burton (1956). The tissue pellet was digested overnight at $30^{\circ} \mathrm{C}$ in $4 \mathrm{ml} 1 \mathrm{M}-\mathrm{KOH}$. Aliquants of this alkaline digest were neutralized with $\mathrm{HCl}$ and radioactivity was determined by scintillation counting using a Triton-toluene-based scintillation fluid.

Leucine incorporation into tissue was assessed as d.p.m. remaining in the tissue per $\mu \mathrm{g}$ DNA; leucine incorporation into secreted protein was assessed as acid-insoluble d.p.m. in the medium for each well $/ \mu \mathrm{g}$ DNA in the tissue in that well. Numerical data were analysed by analysis of variance with data transformed to logarithms when necessary to correct for heteroscedasticity.

Autoradiography. Tissue was fixed in Karnovsky's glutaraldehyde-paraformaldehyde fixative, embedded in paraffin wax and sectioned at $6 \mu \mathrm{m}$. After removal of the wax and rehydration, the sections were dipped in Ilford L 4 emulsion (Ilford, U.K.) and exposed for 2 weeks at $4^{\circ} \mathrm{C}$. The autoradiographs were developed in Kodak D19 developer, after which the sections were stained using haematoxylin and eosin, and mounted under DePeX. Silver grains were localized using bright-field and dark-field microscopy.

\section{Results}

All of the females in the embryo metabolism study had corpora lutea which appeared quiescent at Day 0 , and were enlarged at Day 5 and later stages indicating that they had reactivated. Three females had no blastocyst (one each at Days 0, 7 and 9), and one of the Day-0 blastocysts was lost when it adhered inside a pipette during transfer. The two remaining Day- 0 blastocysts appeared normal, and both had low rates of uptake and incorporation of uridine (Table 1). Although the Day-5 and Day-7 embryos had not expanded, they incorporated uridine at a much greater rate, and all but one Day-5 blastocyst had an increased rate of uptake compared to Day 0 (Table 1). However, 1 of the Day-7 embryos appeared to be abnormal; the protoderm was crumpled when the embryo was recovered and it was smaller than normal. Its rates of uptake and incorporation were 
Table 1. Uptake and incorporation of uridine by blastocysts after removal of pouch young (RPY)

\begin{tabular}{|c|c|c|c|c|c|c|}
\hline \multirow{2}{*}{$\begin{array}{l}\text { Stage } \\
\text { after } \\
\text { RPY }\end{array}$} & \multirow{2}{*}{$\begin{array}{c}\text { Animal } \\
\text { no. }\end{array}$} & \multicolumn{2}{|c|}{ Blastocyst diam. $(\mu \mathrm{m})$} & \multicolumn{2}{|c|}{$\left[{ }^{3} \mathrm{H}\right]$ Uridine (c.p.m.) } & \multirow{2}{*}{ c.p.m. $/ \mathrm{mm}^{2 *}$} \\
\hline & & Shell & Trophoblast & Uptake & Incorporation & \\
\hline \multirow[t]{2}{*}{ Day 0} & 1 & 276 & 204 & 38 & 20 & 242 \\
\hline & Mean & 269 & 210 & 32 & 29 & 266 \\
\hline \multirow[t]{2}{*}{ Day 5} & $\begin{array}{l}3 \\
4 \\
5 \\
6\end{array}$ & $\begin{array}{l}270 \\
264 \\
270 \\
276\end{array}$ & $\begin{array}{l}210 \\
210 \\
215 \\
210\end{array}$ & $\begin{array}{r}42 \\
520 \\
189 \\
241\end{array}$ & $\begin{array}{l}151 \\
132 \\
344 \\
290\end{array}$ & $\begin{array}{r}843 \\
2978 \\
2327 \\
2219\end{array}$ \\
\hline & $\begin{array}{c}\text { Mean } \\
\pm \text { s.e.m. }\end{array}$ & $\begin{array}{r}270 \\
\pm 2\end{array}$ & $\begin{array}{r}211 \\
\pm 1\end{array}$ & $\begin{array}{r}248 \\
\pm 100\end{array}$ & $\begin{array}{r}229 \\
\pm 52\end{array}$ & $\begin{array}{r}2092 \\
\pm 449\end{array}$ \\
\hline \multirow[t]{2}{*}{ Day 7} & $\begin{array}{l}7 \dagger \\
8 \\
9\end{array}$ & $\begin{array}{l}240 \\
288 \\
288\end{array}$ & $\begin{array}{l}125 \dagger \\
256 \\
276\end{array}$ & $\begin{array}{r}70 \\
158 \\
839\end{array}$ & $\begin{array}{r}36 \\
2917 \\
210\end{array}$ & $\begin{array}{r}568 \\
2917 \\
4026\end{array}$ \\
\hline & $\begin{array}{c}\text { Mean } \\
\pm \text { s.e.m. }\end{array}$ & $\begin{array}{r}272 \\
\pm 16\end{array}$ & $\begin{array}{r}219 \\
\pm 47\end{array}$ & $\begin{array}{r}504 \\
\pm 227\end{array}$ & $\begin{array}{r}135 \\
+52\end{array}$ & $\begin{array}{r}2504 \\
\pm 1019\end{array}$ \\
\hline \multirow[t]{2}{*}{ Day 9} & $\begin{array}{l}10 \\
11 \\
12\end{array}$ & $\begin{array}{l}423 \\
276 \\
480\end{array}$ & $\begin{array}{l}-\ddagger \\
268 \\
-\ddagger\end{array}$ & $\begin{array}{r}1581 \\
980 \\
1368\end{array}$ & $\begin{array}{l}187 \\
219 \\
345\end{array}$ & $\begin{array}{l}3016 \\
5010 \\
2367\end{array}$ \\
\hline & $\begin{array}{c}\text { Mean } \\
\pm \text { s.e.m. }\end{array}$ & $\begin{array}{r}396 \\
\pm 62\end{array}$ & & $\begin{array}{l}1310 \\
\pm 176\end{array}$ & $\begin{array}{r}250 \\
\pm 48\end{array}$ & $\begin{array}{r}3464 \\
\pm 795\end{array}$ \\
\hline
\end{tabular}

* Area and volume of the blastocyst calculated from shell diameter.

$\dagger$ Blastocyst with collapsed trophoblast.

$\ddagger$ Not measured.

lower than normal, and were similar to those of the Day-0 blastocysts. Two of the 3 Day- 9 blastocysts had expanded significantly and all 3 showed high rates of uptake and incorporation (Table 1). There appeared to be considerable variability of uptake and incorporation between females at each stage, and no correlation was apparent between these two measures. Similar variability is seen in the results of Thornber $e t$ al. (1981).

The small quantities of uridine taken up and incorporated by the blastocysts indicated that the blastocyst is not freely permeable to uridine. The rate of transfer across the blastocyst membrane (expressed as: c.p.m. (uptake + incorporation/area of trophoblast)) increased from about 250 c.p.m. $/ \mathrm{mm}^{2}$ at Day 0 to about 2000 c.p.m. $/ \mathrm{mm}^{2}$ at Days 5 and 7 . At Day 9 the value was lower in the two larger blastocysts than in the blastocyst that had not yet expanded.

Leucine incorporation was measured in uterine tissue from 16 females after removal of pouch young. Embryos were recovered from 14 of these. The remaining two, one at Day 0 and one at Day 4 , had apparently ovulated as judged by the appearance of the corpus luteum in the ovary but undergone an infertile cycle. No difference was evident in the leucine incorporation of tissue from these females compared to the others at the same stage, and since there is abundant evidence that the endometria of pregnant and non-pregnant marsupials are equivalent at early stages (Hill \& O'Donoghue, 1913; Renfree \& Tyndale-Biscoe, 1973; Shorey \& Hughes, 1973; Renfree, 1973, 1975; Shaw \& Rose, 1979; Fleming \& Harder, 1981a, b), the results from these two non-pregnant females were included with those from pregnant females for statistical analysis.

Leucine incorporation changed markedly after removal of pouch young. By Day 4 there was a 3 -fold increase in protein secretion compared to Day $0(P<0.01)$ for gravid $(1.24 \pm 0.28$ vs

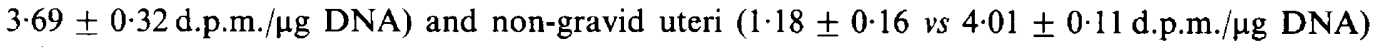
(Fig. 3). Incorporation into tissue also increased by Day 4, although less dramatically (at Days 0 


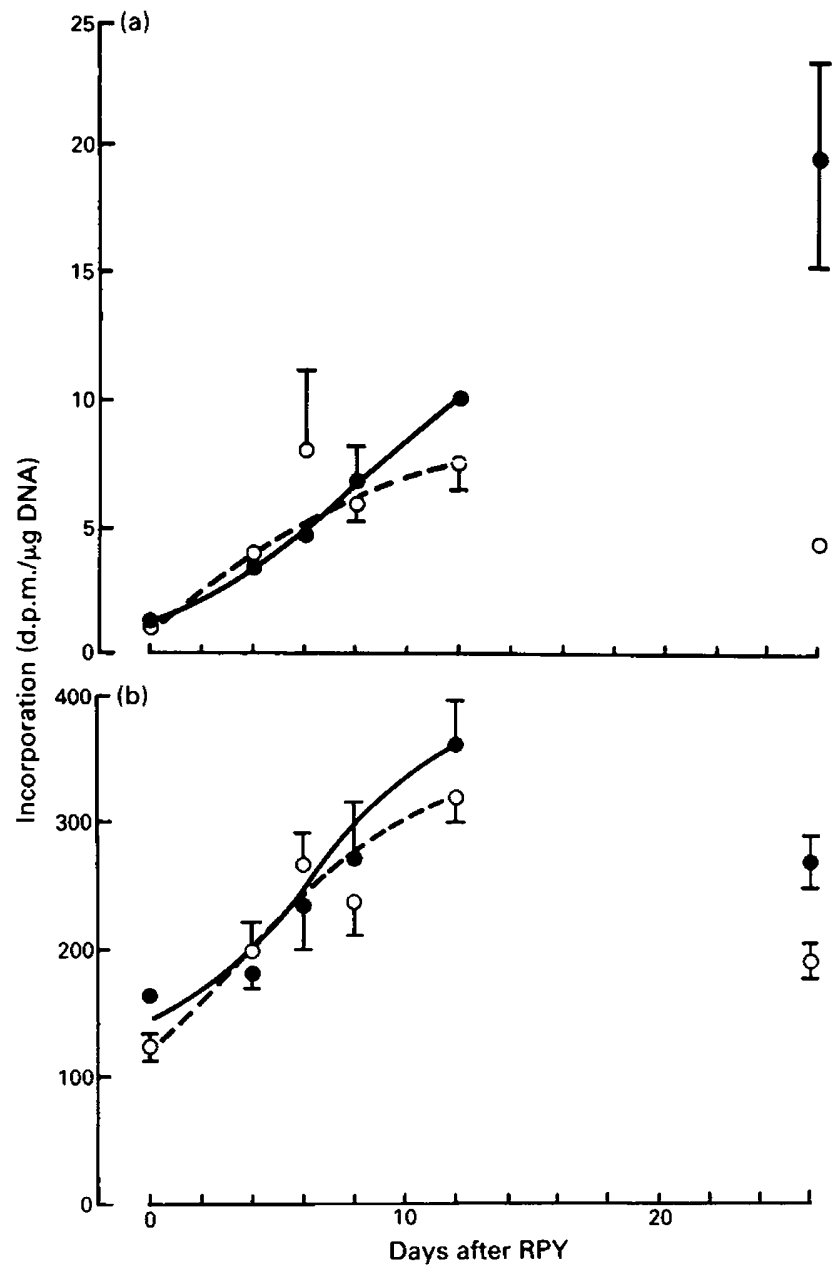

Fig. 3. Leucine incorporation by endometrium into (a) secreted protein and (b) tissue protein. -, Incorporation by gravid uteri (or the uterus ipsilateral to the corpus luteum); $\bigcirc$, non-gravid uteri. The increase in secreted protein is significant $(P<0.05)$ by Day 4 and in tissue protein by Day $6(P<0.05)$.

and 4 gravid uteri had $167 \pm 4$ and $184 \pm 9$ d.p.m./ $\mu$ g DNA, and non-gravid uteri had $124 \pm 11$ and $213 \pm 20$ d.p.m./ $/ \mathrm{g}$ DNA, respectively), and were significantly $(P<0.05)$ increased by Day 6 . Incorporation, both into tissues and secreted protein, continued to increase up to Day 12, with similar rates measured in gravid and non-gravid uteri. From Day 12 to Day 26 there was a 2-fold increase in secretion by the gravid uterus, whilst secretion by the non-gravid uterus declined (Fig. 3 ) and there was a marked difference between the uteri at this stage $(P<0.05)$. Tissue protein, however, declined between Days 12 and 26, and although the gravid endometrium incorporated more leucine than the non-gravid, there was no significant difference between the two sides throughout pregnancy $(P<0.05)$.

Treatment with progesterone or oestradiol for 2 or 3 days stimulated leucine incorporation into secreted and tissue protein to levels well above those seen in quiescent uteri (Fig. 4). Embryos were 

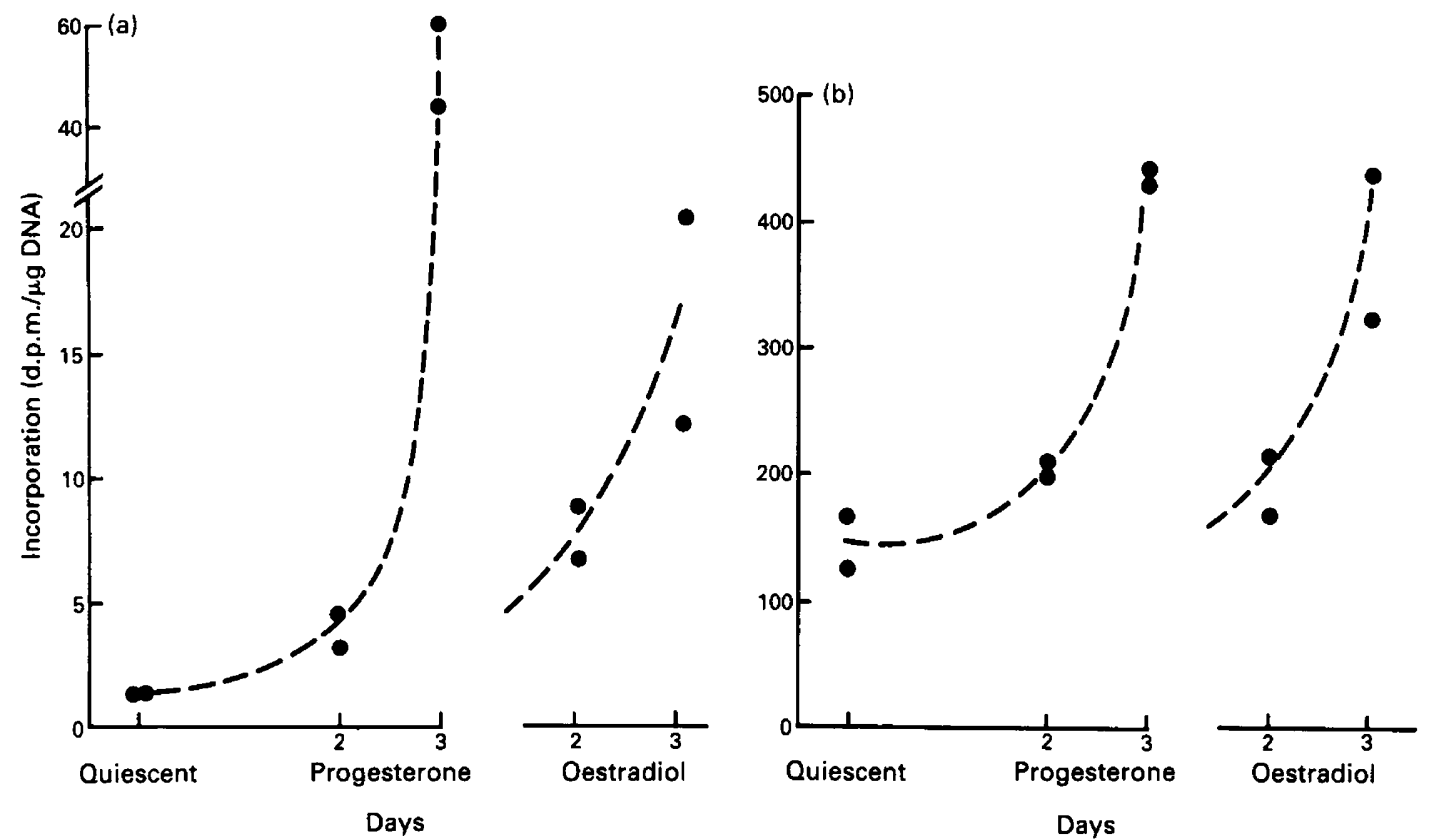

Fig. 4. Leucine incorporation by endometrium from progesterone- and oestradiol-treated females: (a) incorporation into secreted protein; (b) incorporation into tissue protein. A marked increase in incorporation occurs between Days 2 and 3 of treatment.

recovered from both of the progesterone-treated females, and these were indistinguishable from quiescent embryos. Neither of the oestrogen-treated females had blastocysts.

Autoradiographs prepared from incubated tissue showed the label localized mainly over the gland epithelia with a lesser degree of labelling over the stroma.

\section{Discussion}

The results of these studies confirm the observations of Moore (1978) and Thornber et al. (1981) that tammar blastocysts reactivate metabolically at or before Day 5 after removal of pouch young. Uterine reactivation has occurred at least 1 day earlier, at or before Day 4, supporting the contention that a change in uterine secretion causes embryonic reactivation.

Up to Day 12 after pouch young removal adjacent gravid and non-gravid uteri have similar rates of incorporation of leucine into tissue and secreted protein. Similarly, there are only small differences between flushings and exudates from both uteri up to Day 12 (Renfree, 1973; Thornber $e t$ al., 1981). By mid-pregnancy, however, there is a clear difference in the synthesis and secretion of the two uteri. Renfree (1972) and Renfree \& Tyndale-Biscoe (1973) showed that this effect was due to the fetus rather than the proximity of the corpus luteum. The unilateral increase in protein synthesis in the late pregnancy samples observed in this study supports the suggestion that this stimulation may be a local effect of the fetus or placenta, and possibly of placental steroids. However, although the tammar placenta can synthesize progesterone in vitro, the yields are low and less than $1 \%$ conversion of precursors occurs in a 3-h incubation (Heap, Renfree \& Burton, 1980).

It has been suggested that reactivation of the tammar blastocyst is triggered by progesterone from the reactivating corpus luteum (Hinds \& Tyndale-Biscoe, 1982). The present results show that endometrial protein secretion is significantly increased by Day 4 and precedes embryonic reactivation at Day 5. However, the first significant rise in plasma progesterone concentrations and 
secretion by the corpus luteum occurs between Days 4 and 5, and at Day 6 in some animals, peak concentrations occurring on average at Day 5-6 (Hinds \& Tyndale-Biscoe, 1982; Hinds et al., 1983), so it appears that an earlier change is responsible for triggering reactivation. Oestradiol may be a candidate since the uteri responded to exogenous oestradiol with increased secretion. However, like progesterone, oestradiol concentrations on Day 4 are not significantly different from those in diapause, although they rise to a peak on Days 5-6 after removal of pouch young (Shaw \& Renfree, 1984).

This presents a dilemma, because exogenous steroids can reactivate tammar blastocysts and allow pregnancy to proceed to term (Berger \& Sharman, 1969; Renfree \& Tyndale-Biscoe, 1973) although from Ward \& Renfree's (1984) more recent data the plasma concentrations in those studies were probably non-physiological. Many of the failed blastocysts showed abnormal embryonic growth and not all embryos reactivate after this treatment, even when lower doses more in the physiological range were given (Berger \& Sharman, 1969; Renfree et al., 1982). This lack of success in stimulating successful development may result from inappropriate doses or timings, but it remains possible, although unlikely from the evidence presented above, that another hormone could play a role in initiating reactivation from diapause.

An increase in uterine sensitivity to progesterone reflected as a change in receptor concentrations, could also account for a uterine progestational response without a change in plasma concentrations of progesterone. Owen, Cake \& Bradshaw (1982) have demonstrated the presence of progesterone receptors in the uteri of another macropodid marsupial, the quokka, and receptor content was increased by oestradiol treatment. Similarly, in the brush-tailed possum, there is an enhancement of progesterone cytosol receptor synthesis by oestradiol (Curlewis, 1983). A number of other hormones also affect steroid hormone action on the uterus. Thyroid hormones facilitate oestrogen action (Cidlowski \& Muldoon, 1975; Stancel et al., 1979), and pituitary hormones, including prolactin, can affect uterine progesterone receptor content (Daniel, 1980; Daniel, Jetton \& Chilton, 1984). It therefore seems possible that, after removal of pouch young in the tammar, there may be an increased sensitivity of the uterus to progesterone (and/or oestradiol), allowing uterine reactivation to precede changes in plasma concentrations in these steroids. It would be interesting to establish whether the peaks of progesterone and oestradiol at Day 5 are essential for the maintenance of pregnancy, or whether pregnancy could proceed with continued, low concentration of these hormones.

We thank Stuart Green, Alison Dunning and Dr Leigh Findlay for assistance with animal handling and surgery; Dr Elizabeth Thornber for advice on the embryo incubation technique; and Gordon Thompson for autoradiographs of incubated endometrial tissue. This study was supported by grants from the National Institutes of Health (DH-09387) and the Australian Research Grants Scheme (D1-75-15759). G.S. was the recipient of a Commonwealth Postgraduate Award.

\section{References}

Berger, P.J. \& Sharman, G.B. (1969) Progesterone induced development of dormant blastocysts in the tammar wallaby, Macropus eugenii Demarest; Marsupialia. J. Reprod. Fert. 20, 201-210.

Biggers, J.D., Whitten, W.K. \& Whittingham, D.G. (1971) The culture of mouse embryos in vitro. In Methods in Mammalian Embryology, pp. 86-116. Ed. J. C. Daniel, Jr. W. H. Freeman \& Co., San Francisco.

Burton, K. (1956) A study of the conditions and mechanism of the diphenylamine reaction for the colourimetric estimation of deoxyribonucleic acid. Biochem. J. 62, 315-323.
Cidlowski, J.A. \& Muldoon, T.G. (1975) Modulation by thyroid hormones of cytoplasmic estrogen receptor concentrations in reproductive tissues of the rat. Endocrinology 97, 59-67.

Curlewis, J.D. (1983) Some interactions between gonadal steroid hormones and target organs in the male and female brush-tailed possum (Trichosurus vulpecula). Ph.D. thesis, University of Sydney.

Daniel, J.C. (1980) Factors influencing uteroglobin synthesis. In Steroid Induced Uterine Proteins, pp. 87-104. Ed. M. Beato. Elsevier/North Holland, Amsterdam.

Daniel, J.C., Jr, Jetton, A.E. \& Chilton, B.S. (1984) 
Prolactin as a factor in the uterine response to progesterone in rabbits. $J$. Reprod. Fert. 72, 443-452.

Fleming, M.W. \& Harder, J.D. (1981a) Effect of pregnancy on uterine constituents of the virginia opossum. Comp. Biochem. Physiol. 69, 337-339.

Fleming, M.W. \& Harder, J.D. (1981b) Uterine histology and reproductive cycles in pregnant and nonpregnant opossums, Didelphis virginiana. J. Reprod. Fert. 63, 21-24.

Heap, R.B., Renfree, M.B. \& Burton, R.D. (1980) Steroid metabolism in the yolk sac placenta and endometrium of the tammar wallaby, Macropus eugenii. $J$. Endocr. 87, 339-349.

Hill, J.P. \& O'Donoghue, C.H. (1913) The reproductive cycle in the marsupial Dasyurus viverrinus. $Q$. $J l$ Microsc. Sci.59, 113-173.

Hinds, L.A. \& Tyndale-Biscoe, C.H. (1982) Plasma progesterone levels in the pregnant and non-pregnant tammar, Macropus eugenii. J. Endocr. 93, 99-107.

Hinds, L.A., Evans, S.M. \& Tyndale-Biscoe, C.H. (1983) In-vitro secretion of progesterone by the corpus luteum of the tammar wallaby, Macropus eugenii. $J$. Reprod. Fert. 67, 57-63.

Hutchison, W.C. \& Munro, H.N. (1961) The determination of nucleic acids in biological materials. The Analyst 86, 768-813.

Merchant, J.C. (1979) The effect of pregnancy on the interval between one oestrus and the next in the tammar wallaby, Macropus eugenii. J. Reprod. Fert. 56, $459-463$.

Moore, G.P.M. (1978) Embryonic diapause in the marsupial Macropus eugenit. Stimulation of nuclear RNA polymerase activity in the blastocyst during resumption of development. J. Cell Physiol. 94, 31-36.

Owen, F.J., Cake, M.H. \& Bradshaw, S.D. (1982) Characterization and properties of a progesterone receptor in the uterus of the quokka (Setonix brachyurus). J. Endocr. 93, 17-24.

Renfree, M.B. (1972) Influence of the embryo on the marsupial uterus. Nature, Lond. 240, 475-477.

Renfree, M.B. (1973) Proteins in the uterine secretions of the marsupial Macropus eugenii. Devl Biol. 32, 41-49.

Renfree, M.B. (1975) Uterine proteins during gestation in the marsupial, Didelphis marsupialis virginiana. $J$. Reprod. Fert. 42, 163-166.

Renfree, M.B. \& Tyndale-Biscoe, C.H. (1973) Intrauterine development after diapause in the marsupial, Macropus eugenii. Devl Biol. 32, 28-40.

Renfree, M.B., Green, S.W. \& Young, I.R. (1979) Growth of the corpus luteum and its progesterone content during pregnancy in the tammar wallaby, Macropus eugenii. J. Reprod. Fert. 57, 131-136.
Renfree, M.B., Wallace, G.I. \& Young, I.R. (1982) Effects of progesterone, oestradiol-17 $\beta$ and androstenedione on the follicular growth after removal of the corpus luteum during lactational and seasonal quiescence in the tammar wallaby. $J$. Endocr. 92, 397-403.

Shaw, G. \& Renfree, M.B. (1984) Concentrations of oestradiol-17 $\beta$ in plasma and corpora lutea throughout pregnancy in the tammar, Macropus eugenii. $J$. Reprod. Fert. 72, $29-37$.

Shaw, G. \& Rose, R.W. (1979) Delayed gestation in the potoroo, Potorous tridactylus (Kerr). Aust. J. Zool. 27, 901-912.

Shorey, C.D. \& Hughes, R.L. (1973) Cyclic changes in the uterine endometrium, and peripheral plasma concentrations of progesterone in the marsupial Trichosurus vulpecula. Aust. J. Zool. 21, 1-19.

Stancel, G.M., Blatti, S.P., Benson, R.H., Gardner, R.M., Kirkland, J.L., Ireland, J.S., Sidarko, J. \& Weil, P.A. (1979) Hormonal control of uterine growth and regulation of responsiveness to estrogen. In Ontogeny of Receptors and Reproductive Hormone Action, pp. 119-31 1. Eds T. H. Hamilton, J. H. Clark \& W. A. Sadler. Raven Press, New York.

Thornber, E.J., Renfree, M.B. \& Wallace, G.I. (1981) Biochemical studies of intrauterine components of the tammar wallaby Macropus eugenii during pregnancy. J. Embryol. exp. Morph. 62, 325-338.

Tyndale-Biscoe, C.H. (1970) Resumption of development by quiescent blastocysts transferred to primed, ovariectomised recipients in the marsupial, Macropus eugenii. J. Reprod. Fert. 23, 25-32.

Tyndale-Biscoe, C.H. (1979) Hormonal control of embryonic diapause and reactivation in the tammar wallaby. In Maternal Recognition of Pregnancy ( Ciba Fdn Symp. No. 64), pp. 173-190. Ed. J. Whelan. Excerpta Medica, Amsterdam.

Tyndale-Biscoe, C.H. \& Hinds, L.A. (1981) Hormonal control of the corpus luteum and embryonic diapause in macropodid marsupials. J. Reprod. Fert., Suppl. 29, 111-117.

Tyndale-Biscoe, C.H., Hearn, J.P. \& Renfree, M.B. (1974) Control of reproduction in macropodid marsupials. J. Endocr. 63, 589-614.

Tyndale-Biscoe, C.H., Hinds, L.A., Horn, C.A. \& Jenkin, G. (1983) Hormonal changes at oestrus, parturition, and post-partum oestrus in the tammar wallaby (Macropus eugenii). J. Endocr. 96, 155-161.

Ward, K.L. \& Renfree, M.B. (1984) Effects of progesterone on parturition in the tammar (Macropus eugenii). J. Reprod. Fert. 72, 21-28.

Recejved 10 May 1985 